\title{
Occurrence of Guanosine-5'-diphosphate-3'-diphosphate and Adenosine-5'-triphosphate-3'-diphosphate in Streptomyces galilaeus
}

\author{
Yasutaro Hamagishi, Akihiro Yoshimoto, Toshikazu OkI \\ and Taiji INUI \\ Central Research Laboratories, Sanraku-Ocean Co., Lid., \\ 1-9. Johnan 4-chome, Fujisawa, Japan \\ Received August 24, 1979
}

\begin{abstract}
Synthetic activity and existence of ppGpp and pppApp in an anthracycline-producing strain Streptomyces galilaeus were determined by radioimmunoassay and ${ }^{32} \mathrm{P}$-labeling method during cultivation under both the antibiotic productive and non-productive conditions. The cellular ppGpp(pppGpp)-synthesizing activity was highest at the end of exponential growth, and 3-fold higher in the antibiotic-productive cultivation than in non-productive cultivation. The intracellular level of ppGpp determined by radioimmunoassay was high at the end of exponential growth, and afterwards its level decreased by one fifth. The low level of cellular ppGpp during the period of intense antibiotic production suggests that ppGpp consumption may play an important role in antibiotic production of $S$. galilaeus. The concentration of pppApp was not determined intracellularly by radioimmunoassay.
\end{abstract}

ppGpp and pppGpp are important pleiotropic regulatory molecules in bacteria. ${ }^{11}$ Their synthesis in Esherichia coli is catalysed by the stringent factor protein which is coded for the rel A gene, and they are formed on ribosomes not actively engaged in protein synthesis. ${ }^{2)} \mathrm{On}$ the other hand, the extracellular stringent factor-like enzyme, capable of synthesizing ppGpp and pppApp, was found to be present in Streptomyces cultures. ${ }^{3 \sim 5)}$ Futhermore, recently Simuth et al. ${ }^{6)}$ and An and Vining ${ }^{73}$ identified ppGpp, pppGpp, ppApp and pppApp in the vegitative mycelia of streptomycin-producing $S$. griseus and chlorotetracycline-producing $S$. aureofaciens.

\footnotetext{
Abbreviations: Guanosine-5'-triphosphate-3'-diphosphate $=$ pppGpp; guanosine- $5^{\prime}$-diphosphate- $3^{\prime}$-diphosphate $=$ ppGpp $;$ guanosine- $-5^{\prime}$-monophosphate- $3^{\prime}$-diphosphate $=$ pGpp $; \quad$ guanosine- $5^{\prime}$-diphosphate- $3^{\prime}$ (or $2^{\prime}$ )monophosphate $=\mathrm{ppGp} ; \quad$ adenosine $-5^{\prime}$-triphosphate $-3^{\prime}-$ diphosphate $=$ ppApp; $\quad$ adenosine- $5^{\prime}$-diphosphate- $3^{\prime}-$ diphosphate $=$ ppApp; $\quad$ adenosine $-5^{\prime}-$ monophosphate- $3^{\prime}-$ diphosphate $=$ pApp; $\quad$ guanosine $-5^{\prime}$-tetraphosphate $=$ ppppG: $100 \mathrm{~mm}$ Tris- $\mathrm{HCl}$ buffer, pH 7.5 , containing $0.15 \mathrm{M} \mathrm{NaCl}$ and $0.1 \% \mathrm{NaN}_{3}=\mathrm{TBS}$.
}

Therefore, we have been interested in possible roles of the enzyme and its products containing ppGpp and pppApp on the cell growth and cellular metabolism in Streptomyces.

Assay for intracellular highly phosphorylated nucleotides usually consists of culturing the organisms or cells with $\mathrm{H}_{3}{ }^{32} \mathrm{PO}_{4}$, extraction with acid (usually formic acid), and PEIcellulose thin-layer chromatographic separation of the products. However, ${ }^{32} \mathrm{P}$-labeling method is complicated, and time-consuming with low accuracy. We, therefore, developed radioimmunoassay for ppGpp and pppApp ${ }^{8.9)}$

This report deals with the determination of intracellular ppGpp and pppApp levels in Streptomyces galilaeus MA144-M1 by radioimmunoassay, and the relationship between their changes in intracellular concentration and the onset on the production of, antitumor anthracycline antibiotic, aclacinomycin.

\section{MATERIALS AND METHODS}

Chemicals. $\left[2-{ }^{14} \mathrm{C}\right]$-uridine $(50 \mathrm{mCi} / \mathrm{mmol}),\left[1{ }^{14} \mathrm{C}\right]-$ leucine $(50 \mathrm{mCi} / \mathrm{mmol})$ and $\left[{ }^{32} \mathrm{P}\right]-\mathrm{H}_{3} \mathrm{PO}_{4}$ (carrier free) were 
obtained from the Radiochemical Centre Amersham. The nucleoside polyphosphate lithium salts, pppApp, ppApp, pppGpp, ppGpp, pGpp and pApp, were our products (Sanraku-Ocean Co., Japan) prepared by ATP: nucleotide pyrophosphotransferase. ${ }^{41}$ Other common nucleotides were purchased from Sigma Chemical Co.

Strains, media and growth conditions. Streptomyces galilaeus MA144-M1, strain No. 6U-2l capable of producing highly anthracycline antibiotic aclacinomycin $\mathrm{A}^{\mathrm{j} 01}$ was used. YS medium consisted of $0.3 \%$ yeast extract and $1 \%$ soluble starch, pH 7.2 and permitted the antibiotic production at a moderate yield. A modified YS medium with enhanced yeast extract by $1 \%$ was used as the antibioticnon-productive condition. The cultivation was carried out in a $500-\mathrm{ml}$ Erlenmeyer flask containing $50 \mathrm{ml}$ of the medium at $28^{\circ} \mathrm{C}$ on a rotary shaker $(220 \mathrm{rpm})$.

Cellular activity of $p p G p p$ ( $p p p G p p$ )-synthesis. At appropriate time intervals, $0.2 \mathrm{ml}$ of cultured broth of $S$. galilaeus was withdrawn, added to a small tube $(1.0 \times 10 \mathrm{~cm})$ containing $10 \mu \mathrm{l}$ of $\left[{ }^{32} \mathrm{P}\right]-\mathrm{H}_{3} \mathrm{PO}_{4}(4 \mathrm{mCi} / \mathrm{ml})$ and incubated at $30 \% \mathrm{C}$ on a reciprocal shaking incubator for $30 \mathrm{~min}$. It was then mixed with $20 \mu \mathrm{l}$ concd. formic acid. After $20 \mathrm{~min}$ at $0^{\circ} \mathrm{C}$, the mixture was centrifuged and the supernatant was removed, quickly frozen and stored at $-40^{\circ} \mathrm{C}$ until used for determination. Five or ten $\mu$ l of the supernatant were spotted on polyethyleneimine-cellulose (PEI-cellulose) sheets (Machery-Nagel MN-300 PEIcellulose) with authentic ATP, GTP, pppGpp, ppGpp, pppApp and ppApp as markers. Nucleotides were resolved by either one- or two-dimensional ascending chromatography. For two-dimensional chromatograms a solution containing $3.3 \mathrm{M}$ ammonium formate and $4.2 \%$ boric acid adjusted to $\mathrm{pH} 7$ with ammonium hydroxide was used to develop in the first direction. The chromatogram was dried, soaked in methanol for $30 \mathrm{~min}$, and dried again before the second development in $1.5 \mathrm{M}$ potassium phosphate buffer, $\mathrm{pH}$ 3.4. For one-dimensional chromatography the latter solvent was used. ${ }^{32}$ P-labeled compound were detected by exposing the chromatogram to X-ray film (Kodak noscreen medical X-ray film, Eastman Kodak Corporation, Rochester, New York). Identification of nucleotides solely on the basis of one-dimensional chromatography is very hazardous as pointed out by Gallant and Margasson. "1) For example, in one-dimensional chromatography, the ${ }^{32}$ P-labeled compounds that comigrated with ppGpp and pppGpp reference marker were present in the acid-cell extracts of $S$. galilaeus (Fig. 1-A). By two-dimensional chromatography these spots were clearly separated from ppGpp and pppGpp (Fig. 1-B,C.D). The radioactive spots comigrated with authentic ppGpp or pppGpp were cut out and counted in the Bray scintillator by a Aloka Scintillation Spectrometer Model LSC 653.

Radioimmunoassay for $p p G p p$ and pppApp. Radioimmunoassay for ppGpp was performed by using antibody for ppGpp-human serum albumin, and that for pppApp was performed by using antibody for 8-(6aminohexyl)amino-pppApp-human serum albumin. Assay methods are described in details in the preceding papers. ${ }^{8.91}$

Pretreatment of radioimmunoassay samples. Five $\mathrm{ml}$ of the culture broth sampled at appropriate time intervals were separated into the supernatants and mycelia by centrifugation. The mycelial pellet was rinsed twice with $5 \mathrm{ml}$ of cold $0.15 \mathrm{M} \mathrm{NaCl}$ and mixed with $5 \mathrm{ml}$ of $0.2 \mathrm{~N}$ formic acid. After $20 \mathrm{~min}$ at $0^{\circ} \mathrm{C}$, the mixture was centrifuged and the supernatant was removed and neutralized with $1 \mathrm{~N} \mathrm{NaOH}$ in ice-water bath. The supernatant was diluted twice with distilled water and applied on the column of DEAE-Sephadex A-25 (1.0×3.0 cm, $\mathrm{HCO}_{3}{ }^{-}$form). After rinsing with $20 \mathrm{ml}$ of the water, the column was eluted with $20 \mathrm{ml}$ of $0.3 \mathrm{M} \mathrm{NH}_{4} \mathrm{HCO}_{3}$ and then with $20 \mathrm{ml}$ of $0.6 \mathrm{M}$ $\mathrm{NH}_{4} \mathrm{HCO}_{3} ; 0.3 \mathrm{M} \mathrm{NH}_{4} \mathrm{HCO}_{3}$ eluent was served to elute out most of all nucleoside (mono, di and tri)-phosphates including ppGp, pGpp and $\mathrm{pApp}$, and subsequent $0.6 \mathrm{M}$ $\mathrm{NH}_{4} \mathrm{HCO}_{3}$ eluate contained ppGpp, pppGpp, ppApp, pppApp and ppppG. The latter pools were freezed-dried. The residues were dissolved in $1 \mathrm{ml}$ of TBS (100 mM Tris$\mathrm{HCl}$ buffer, $\mathrm{pH} 7.5$, containing $0.15 \mathrm{M} \mathrm{NaCl}$ and $0.1 \%$ $\mathrm{NaN}_{3}$ ) and assayed for ppGpp and pppApp. When 1000 pmol ppGpp or pppApp was applied, recovery from column was quantitative.

Determination of RNA and protein synthesis. From the growing culture of $S$. galilaeus at different times $0.2 \mathrm{ml}$ sample was withdrawn and incubated with $20 \mu \mathrm{l}$ of $\left[{ }^{14} \mathrm{C}\right]-$ uridine $(0.5 \mu \mathrm{Ci} / \mathrm{ml})$ or $20 \mu \mathrm{l}$ of $\left[{ }^{14} \mathrm{C}\right]$-leucine $(4.5 \mu \mathrm{Ci} / \mathrm{ml})$ at $30^{\circ} \mathrm{C}$ for $5 \mathrm{~min}$, and two drops of $1 \%$ bovine serum albumin and $0.2 \mathrm{ml}$ of cold $10 \%$ trichloroacetic acid, the sediment was dissolved in $0.2 \mathrm{ml}$ of concd. formic acid at $100^{\circ} \mathrm{C}$ for $10 \mathrm{~min}$ and measured for the radioactivity in Bray scintillator.

Aclacinomycin production and protein assay. At appropriate time intervals, aclacinomycin $\mathrm{A}$ and its analogs were extracted with $5 \mathrm{ml}$ of chloroform from $5 \mathrm{ml}$ of sample broth. The chloroform extract was concentrated in vacuo, and the residue was dissolved in $5 \mathrm{ml}$ of methanol. Amount of aclacinomycins was determined by the measurement of absorbance at $430 \mathrm{~nm}^{101}{ }^{10}$ Protein content was determined by the method of Lowry et al, using bovine serum albumin (Seikagaku Kogyo Co.) as a standard. ${ }^{12)}$

\section{RESULTS AND DISCUSSION}

\section{Biosynthesis of highly phosphorylated nu- cleotides, RNA and protein}

ppGpp (pppGpp)-synthesizing activity and cellular level of ppGpp were monitored during cultivation under both of the antibiotic productive and non-productive conditions. Figure 

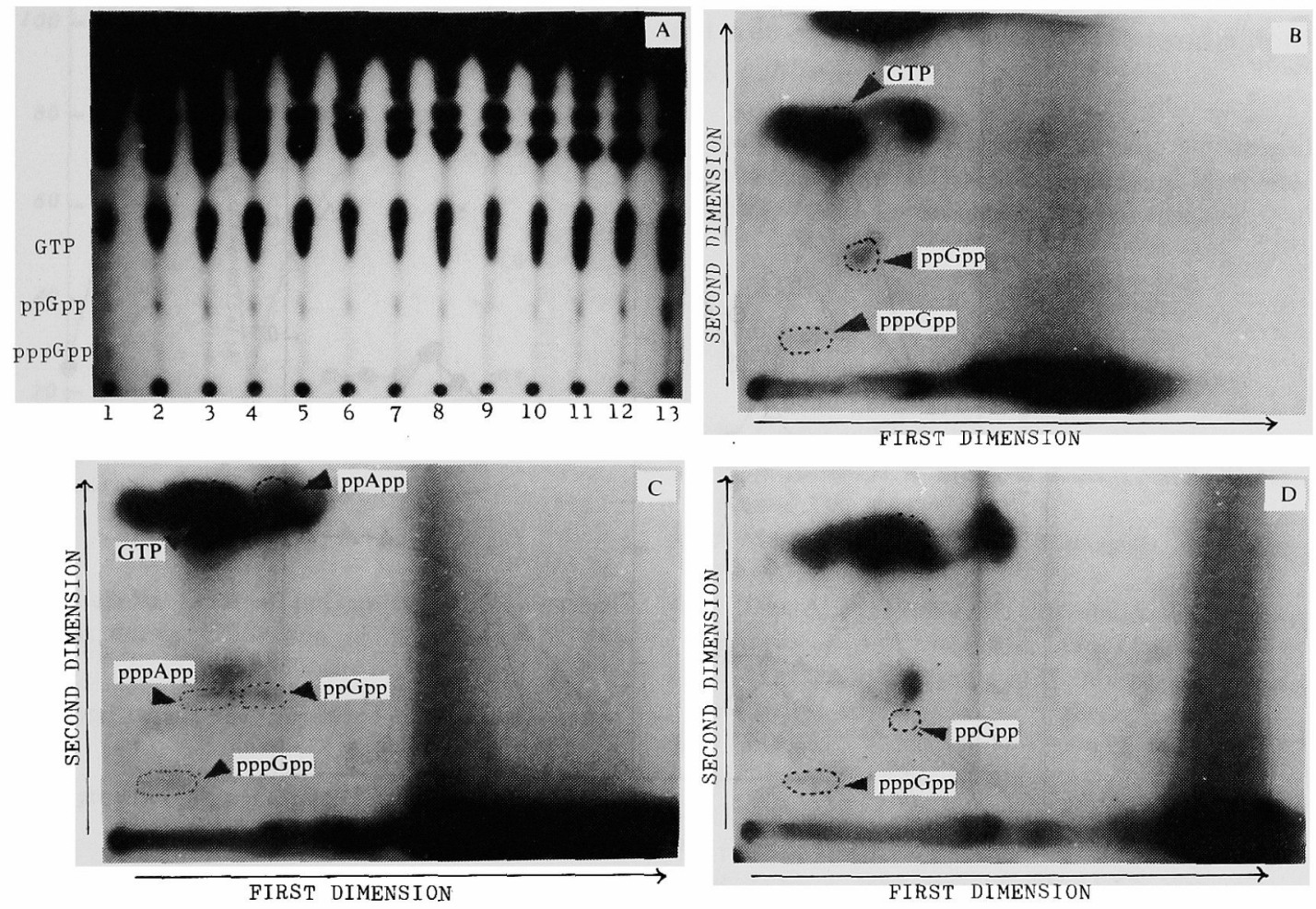

FIG. 1. Autoradiogram of a Thin-layer Chromatogram of the Acid-soluble Fractions from $S$. galilaeus Grown in YS Medium.

Experimental details were described in MATERIALS AND METHODS. Dotted circles indicated the positions of unlabeled reference nucleotides which were cochromatographed with the sample and located under ultraviolet light.

One-dimensional thin-layer chromatogram:

(A) Culturing time (hr): (1), 10; (2), 15; (3), 20; (4), 25; (5), 30; (6), 35; (7), 40; (8), 45; (9), 50; (10), 55; (11), 60;

(12), 65; (13), 70 .

Two-dimensional chromatogram:

(B) $20 \mathrm{hr}$; (C) $30 \mathrm{hr}$; (D) $60 \mathrm{hr}$.

2-A shows the time-course of the macromolecular synthesis, aclacinomycin formation and ppGpp (pppGpp)-synthesizing activity during cultivation in YS medium (antibiotic productive condition). The culture grew exponentially until about $25 \mathrm{hr}$ and the cell mass reached to a plateau. A pulse-label with $\left[{ }^{14} \mathrm{C}\right]-$ uridine and $\left[{ }^{14} \mathrm{C}\right]$-leucine showed that intense RNA synthesis already ended before the exponential growth while decrease in the protein synthesis occurred about $20 \mathrm{hr}$ later than that in the RNA synthesis. The aclacinomycin production initiated at the end of exponential growth (about $30 \mathrm{hr}$ ). The cellular ppGpp
(pppGpp)-synthesizing activity of $S$. galilaeus was highest at the end of exponential growth in YS medium.

Similar RNA and protein levels in $S$. $g a$ lilaeus were observed in a modified YS medium (antibiotic-non-productive condition), as shown in Fig. 2-B. However, the cellular ppGpp (pppGpp)-synthesizing activity was $3 \sim 10$ fold lower than in productive cultivation. These results coincided with those obtained in the chlortetracycline-producing and non-producing strains as reported by Simuth et al., ${ }^{6)}$ and suggest that the ppGpp (pppGpp) may have an important role in the 


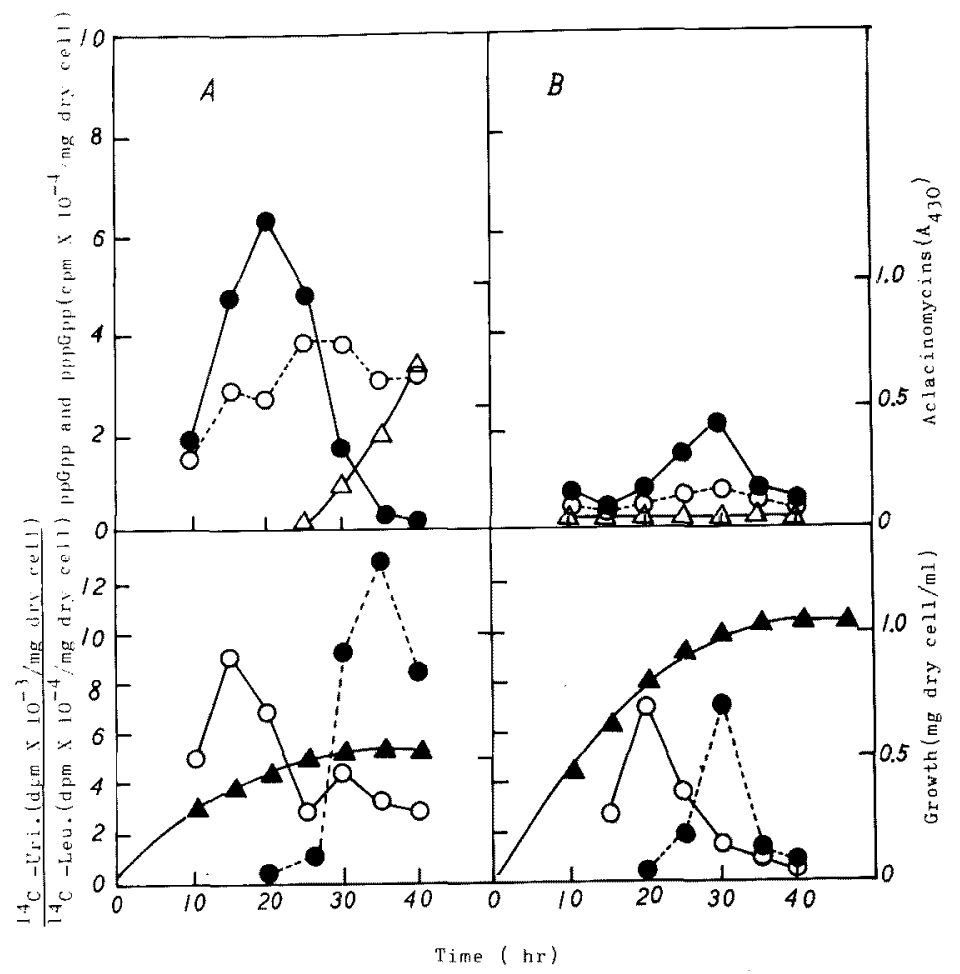

FIG. 2. Cellular ppGpp(pppGpp)-synthesizing Activity, Macromolecular Synthesis, and Aclacinomycin Production in S. galilaeus Grown in YS (A) and a Modified YS (B) Media.

Experimental details were described in Materials and Methods.

Symbols: growth (- - - ) incorporation of $\left[{ }^{14} \mathrm{C}\right]$-uridine $(-\mathrm{O}-)$ and $\left[{ }^{14} \mathrm{C}\right]$-leucine (-- --); synthetic activities of ppGpp (- $\rightarrow$ ) and pppGpp (- $\left.{ }^{-}-\right)$; aclacinomycin $(-\triangle \longrightarrow)$.

exponential growing cells.

Determination of intracellular $p p G p p$ and pppApp by radioimmunoassay

Concentration of ppGpp and pppApp in the mycelium of $S$. galilaeus grown in antibioticproductive and non-productive media were determined by radioimmunoassay, as shown in Table I. The level of ppGpp was 1.5-fold higher in antibiotic-productive cultivation than in non-productive cultivation. This result agrees with that of ppGpp-synthesizing activity as described above, which was assayed by ${ }^{32} \mathrm{P}$ labeling method. pppApp was not detected in the acid-cell extracts of $S$. galilaeus by radioimmunoassay. However, as shown in Fig. 1-C, autoradiogram of a two-dimensional chromatogram of the acid-extracts prepared from $30 \mathrm{hr}$-cultivated cells showed the presence of
${ }^{32} \mathrm{P}$-labeled compounds comigrated with ppApp and pppApp, which were adsorbed by activated charcoal. These compounds could not be detected in the exponential $(20 \mathrm{hr})$ and stationary ( $60 \mathrm{hr}$-cultivation) phases. These results suggest that pppApp and ppApp are

TABLE I. INTRACELlular LeVELS of ppGpp AND pppApp IN $S$. galilaeus

\begin{tabular}{|c|c|c|}
\hline Cultivation time $(\mathrm{hr})$ & ppGpp & pppApp \\
\hline YS medium & $\begin{array}{c}\text { (pmol/mg cell } \\
\text { protein) }\end{array}$ & $\begin{array}{c}\text { (pmol/mg cell } \\
\text { protein) }\end{array}$ \\
\hline 20 & 88.6 & $<2.8$ \\
\hline 30 & 8.0 & $<2.8$ \\
\hline \multicolumn{3}{|l|}{ Modified YS medium } \\
\hline 20 & 51.9 & $<0.9$ \\
\hline 30 & 34.5 & $<0.9$ \\
\hline
\end{tabular}

Experimental details were described in "MATERIALS AND METHODS." 


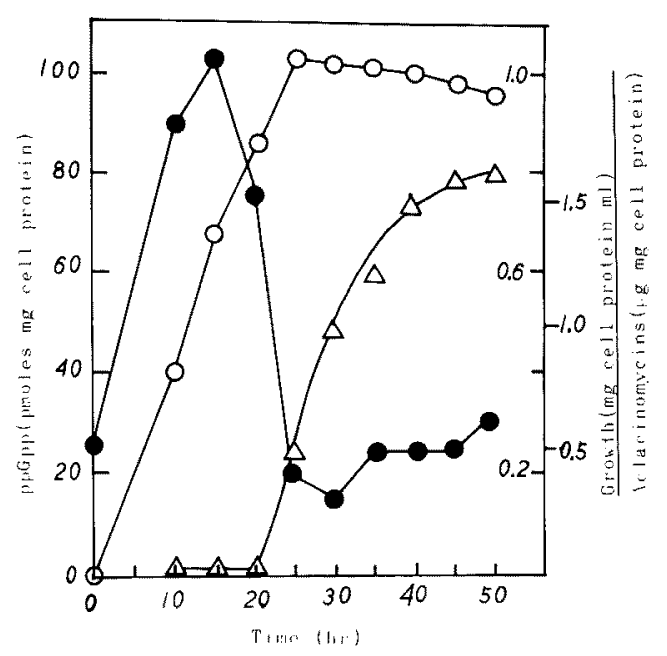

FIG. 3. Cellular Level of ppGpp and Aclacinomycin Production during Cultivation of $S$. galilaeus in YS Medium.

Experimental details were described in MATERIALS AND Methods.

Symbols: growth (O); ppGpp (๑); aclacinomycin $(\triangle)$.

present in $S$. galilaeus, but that their intracellular levels are very low.

Figure 3 shows the cellular levels of ppGpp and aclacinomycin production in $S$. galilaeus in YS medium. The cellular concentration of ppGpp was high at the end of exponential growth and ranged about $90 \mathrm{pmol} / \mathrm{mg}$ cell protein, and afterwards its level decreased by one fifth. The low level of cellular ppGpp during intense antibiotic production suggests that ppGpp consumption may play an important role on the onset of antibiotic-production in $S$. galilaeus.

Acknowledgment. We wish to express our sincere thanks to Prof. Hamao Umezawa, Institute of Microbiol Chemistry, Tokyo, for his kind advice and criticism.

\section{REFERENCES}

1) M. Cashel and J. Gallant, Nature, 221, 838 (1969).

2) W. A. Haseltine, R. Block, W. Gilbert and K. Weber, Nature, 238, 381 (1972).

3) S. Murao, T. Nishino and Y. Hamagishi, Agric. Biol. Chem., 38, 887 (1974).

4) T. Oki, A. Yoshimoto, M. Sato and A. Takamatsu, Biochem. Biophys. Acta, 410, 262 (1975).

5) Y. Hamagishi, T. Nishino and S. Murao, Agric. Biol. Chem., 39, 1015 (1975).

6) J. Simuth, J. Hudec, T. H. Chau, O. Danyi and J. Zelinka, J. Antibiot., 3253 (1979).

7) G. An and L. C. Vining, Can. J. Microbiol, 24, 502 (1978).

8) H. Tone, Y. Hamagishi, T. Oki and T. Inui, Agric. Biol. Chem., 43, 2007 (1979).

9) Y. Hamagishi, T. Oki, H. Tone and T. Inui, Biochem. Biophys. Res. Commun, to be submitted

10) T. Oki, Y. Matsuzawa. A. Yoshimoto, K. Numata, I. Kitamura, S. Hori, A. Tamatsu, H. Umezawa, M. Ishizuka, H. Nagasawa, H. Suda, H. Hamada and T. Takeuchi, J. Antibiot., 28, 830 (1975).

11) J. Gallant and G. Margarson, J. Biol. Chem., 247, 2289 (1972)

12) O. H. Lowry, N. J. Robebrough, A. L. Farr and R. L. Randall, J. Biol. Chem., 193, 265 (1951). 